\title{
Potential Therapeutic Targets in People with Emotional Dependency
}

Objetivos terapéuticos potenciales en personas con dependencia emocional

Mariantonia Lemos ${ }^{1, *}$, Andrés Miguel Vásquez ${ }^{1}$ and Juan Pablo Román-Calderón ${ }^{1}$

\begin{abstract}
Objective: To examine the relationship between the components of emotional dependency (ED) with anxious, depressive, and impulsive symptomatology. Method: 98 university students (68\% women, age $M=20.2$ years, $E D=2.19)$ responded to the ED Questionnaire $(E D Q)$ (Lemos \& Londoño, 2006), the Beck Depression Inventory II (Beck, Steer, \& Brown, 2011), the Beck Anxiety Inventory (Beck \& Steer, 2011), and the short version of the Barratt Impulsiveness Scale BIS-15S (Spinella, 2007). Results: The structural model indicated that a fear of being alone is associated with separation anxiety, which in turn gives rise to plan modification (PM), search for emotional expression (SEE) and attention-seeking (AS). We found that PM was associated with depression, SEE with anxiety, and that impulsivity could lead to AS. Conclusion: These results identify potential therapeutic targets in people with ED.

\section{Resumen}

Objetivo: Examinar la relación entre los componentes de la dependencia emocional (DE) con sintomatología ansiosa, depresiva e impulsividad. Método: 98 estudiantes universitarios (68\% mujeres, edad $M=20.2$ años, $D E=2,19)$ respondieron el Cuestionario de DE (CDE) (Lemos \& Londoño, 2006), el inventario de depresión de Beck II (Beck, Steer, \& Brown, 2011) y el de ansiedad (Beck \& Steer, 2011) y la escala de impulsividad de Barratt en su versión reducida BIS-15S (Spinella, 2007). Resultados: el modelo estructural señaló que el miedo a la soledad se asocia con la ansiedad de separación, de la que se despliegan las estrategias de modificación de planes (MP), búsqueda de expresión afectiva (BEA) y búsqueda de atención (BA). Se observó asociación de MP con depresión, de BEA con ansiedad, y que la impulsividad podría llevar a la BA. Conclusión: Estos resultados señalan blancos terapéuticos en personas con DE.
\end{abstract}

\section{Keywords:}

Dependency, Anxiety, Depression, Impulsivity, Structural Equation Models.

Palabras Claves:

dependencia, ansiedad, depresión, impulsividad, modelos de ecuaciones estructurales.

\section{Introduction}

Emotional dependency (ED) refers to a chronic pattern of unmet affective demands, which individuals desperately seek to meet through close interpersonal relationships (Castelló, 2002, 2005). This has been seen as genuine relational dependency; that is, not one that is mediated by other affective disorders (Sirvent, 2000), in which the difference established between an individual with this pattern of illness and an individual with healthy affect patterns are purely quantitative (Lemos \& Londoño, 2006). It is worth noting that other authors have written about love addiction (Schaeffer, 1998), interpersonal dependency (Hirschfeld et al., 1977) or emotional dependency in a marital relationship (Rathus \& O'Leary, 1997), among others. However, in recent years, the use of the ED construct has been consolidated to refer to a personality trait or pattern of excessive dependency on others (Urbiola, Estévez, \& Iraurgi, 2014). 
ED involves cognitive, emotional, motivational, and behavioral components which are associated with each other and reflect the beliefs of subjects and their strategies to cope with the unease produced by possible abandonment by and control over the partner (Jaller \& Lemos, 2009; Urbiola et al., 2014). According to Lemos \& Londoño (2006), beliefs are associated with a fear of being alone and separation anxiety, and the strategies used include plan modification, a need for emotional expression, attention-seeking, and borderline behavior in a case of imminent abandonment. It is worth noting that similar components have been described in other studies such as those by Urbiola et al. (2014) who showed that ED in a relationship is characterized by an avoidance of being alone, the need for exclusivity, people-pleasing behavior, and an asymmetric relationship. Villa Moral Jiménez and Sirvent Ruiz (2009) state that the behavior of an individual with ED is similar to that of an individual with substance dependence, revealing an irresistible longing to be with the person who is the object of dependence, a compulsive need for his or her presence, and negative reactions in his or her absence. These factors would lead the individual to accommodate to the partner's wishes, suffer an emotional void, present no awareness of the problem, and feel bound to the relationship.

With respect to prevalence, a literature review carried out in 2016 indicated that figures between 5\% and $24.5 \%$ have been reported, and that ED is a very important problem given its association with different profiles, in particular, gender-based violence (Bution \& Wechsler, 2016). In this respect, the results of the studies indicate that emotional dependency would be associated with suicidal ideation in university students (Siabato \& Salamanca, 2015), partner violence (Del Castillo, Hernández, Romero \& Iglesias, 2015; de la Villa, García, Cuetos \& Sirvent, 2017; Loinaz \& Echeburúa, 2012; Álvarez-Dardet, Pérez-Padilla, \& Lorence-Lara, 2013; Preciado-Gavidia, Torres-Cendales, \& Rey-Anacona, 2012; Urbiola, Estévez, Iruarrizaga, \& Jauregui, 2017), depressive and depression symptomatology (Davila, Steinberg, Kachadourian, Cobb, \& Fincham, 2004; Urbiola et al., 2017), anxiety symptoms (Urbiola et al., 2017), personality disorders (Bornstein, 1998; Morse, Robins, \& Gittes-Fox, 2002), and Internet and cell phone addiction (Estévez, Urbiola, Iruarrizaga, Onaindia, \& Jauregui, 2017), among other psychopathological profiles (Santamaría et al., 2015).

It is important to point out that a more detailed analysis of psychopathological profiles and problem behaviors associated to ED would point to common underlying factors. A number of studies have shown that significant anxiety or depressive symptomatology underlies addictive behaviors such as Internet and cell phone addiction (Ballarotto, Volpi, Marzilli, \& Tambelli, 2018; Caplan, 2007; Ho et al., 2014; Poorakbaran,
2015; Reed et al., 2017; Wiener et al., 2018), and it has been found that partner violence has associated emotional factors and components of impulsivity (Ahmadzad-Asl, Davoudi, Zarei, Mohammad-Sadeghi, \& Rasoulian, 2016; Lewis et al., 2017; Shaikh, Pearce, \& Yount, 2017). Finally, it has been reported that suicidal behavior may be preceded to a great extent by depression, anxiety, or impulsivity (Najafi, Mamazandi, \& Balutbangan, 2017; Palmier-Claus, Taylor, Varese, \& Pratt, 2012).

With respect to the latter three factors, Estévez et al. (2017) reported that in Spanish university students, depression and anxiety are associated with an avoidance of being alone, while asymmetric relationships tend to be associated with depressive symptomatology. In another study by Urbiola et al. (2017) involving a Spanish population, the authors reported that avoidance of being alone is the only component of ED which is associated with anxiety. Yet another sample of Spanish teenagers surveyed using the Emotional Dependency in Dating Relationships Questionnaire (Estévez et al., 2018) revealed that impulsivity is associated with ED and all of its components.

In sum, research on ED indicates the existence of some basic related characteristics; however, the relationship between the components (beliefs and strategies) has been hypothesized but not verified experimentally. Most of the studies that have associated ED with psychopathology or problem behavior have done so in a general manner and not through its components, except the studies mentioned above involving Spanish populations. The above is considered relevant from a perspective of clinical psychology, as an identification of the beliefs, threats, or behavioral strategies would guide psychotherapy more effectively towards changing the patient's beliefs or behaviors (Clark \& Beck, 2010). As such, this study responds to the need to examine the relationship between the components of ED and their association with impulsivity, anxiety, and symptoms of depression. Clarifying these relationships allows us to understand the profile in order to identify potential therapeutic targets for patients with ED.

\section{Method}

\section{Design}

This is a quantitative, cross-sectional, descriptive and correlational study. It is descriptive inasmuch as it specifies the characteristics and profiles of people, groups or communities; and correlational in that it points to the association between two or more variables in one context (Hernández, Fernández \& Baptista, 2006). 


\section{Population and sample}

The reference population was made up of university students from four private universities in Medellín. The inclusion criteria were as follows: to be of legal age and to have signed the informed consent form. Students with cognitive, neurological, psychiatric, or motor impairment that hindered response capacity to psychological tests were excluded. The sampling was purposive, seeking to include similar proportions of students from each of the universities. The sample included 98 university students, $68 \%$ women $(n=67)$, with an average age of 20.2 years (D.T. $=2.19$ ) and an age range of 18 to 29 . Some $46 \%$ of the sample was in a relationship at the time of assessment.

\section{Assessment instruments}

Emotional Dependency Questionnaire - EDQ (Lemos \& Londoño, 2006). This questionnaire was created to evaluate ED measured by its six components. It is a 23-item scale with appropriate reliability ( $\mathrm{a}=$ 0.93 for the total scale, a between 0.62 and 0.87 for the subscales) and validity levels in the university population. A subsequent confirmatory factorial analysis corroborated that the scales for separation anxiety, emotional expression from the partner, plan modification, fear of being alone, and attention seeking have an average extracted variance of above $53 \%$ and a composite reliability of above 0.75 . It was also found that the EDQ presented a strong degree of metric invariance between sexes and whether a partner was present or not (Lemos, Vásquez-Villegas \& RománCalderón, 2019). The Cronbach's alpha for the scale in this study was of 0.92 .

Beck Depression Inventory, second edition, Spanish version - BDI-II (Beck, Steer, \& Brown, 2011). This is a 21-item self-administered questionnaire that assesses the severity of depressive symptomatology in adults and teenagers. It is an updated version of the first edition (Beck, Ward, Mendelson, Mock, \& Erbaugh, 1961) that contains current criteria for the diagnosis of depression (Beck et al., 2011). The reliability indices of the original version (0.92) and the Spanish version (between 0.87 and 0.91 ) are appropriate. The factorial analyses in both validations revealed the existence of two main factors that explain the greatest proportion of the variance and are related to the somatic and cognitive symptomatology of depression (Beck et al., 2011; Sanz, García-Vera, Espinosa, Fortún, \& Vázquez, 2005; Sanz, Navarro, \& Vazquez, 2003; Sanz, Perdigón, \& Vazquez, 2003). The reliability index obtained for the BDI-II for the sample was of 0.88 .

Beck Anxiety Inventory - BAI, Spanish version (Beck $\&$ Steer, 2011). This is a self-administered questionnaire for anxiety symptoms and their severity in adults and teenagers. The original validation presents a high level of internal consistency $(a=0.92)$, and the test-retest applied one week apart showed a correlation of 0.75 . For concurrent and divergent validity, Beck and Steer (2011) reported correlations with different anxiety and depression tests: 0.51 with the Hamilton Anxiety Scale, 0.48 with the Beck Depression Inventory, and 0.47 and 0.58 with the subscales of state anxiety and trait anxiety, respectively, from the State-Trait Anxiety Inventory (STAI). The Spanish validation also presented appropriate internal consistency indices (between 0.85 and 0.93) (Sanz \& Navarro, 2003). A Cronbach's alpha of 0.91 was obtained for this study.

Barrat Impulsivity Scale -BIS (Patton, Stanford, \& Barratt, 1995) in its short version -BIS-15S (Spinella, 2007) and validated in a Colombian population (Orozco-Cabal, Rodríguez, Herin, Gempeler, \& Uribe, 2010). This is a 15 -item self-administered questionnaire based on a Likert scale of 1 (rarely or never) to 4 (always or almost always). The test was translated into Spanish by Oquendo et al. (2001), who analyzed the main components and selected the five items with the highest loads. The internal consistency index for the original version was 0.81 and in the Colombian version, it was 0.79 . The reliability index in the assessed sample was of 0.80 .

\section{Procedure}

In each university, participants were invited directly and individually by a research assistant who explained the study objectives to the potential candidates. Those who accepted signed the informed consent form and were subsequently given the assessment protocol to fill out. This study complied with all of the ethical standards for research involving human beings.

\section{Statistical analysis}

The PLS structural equation modeling (PLS-SEM) was chosen given the presence of latent variables in the specified model and the sample's relatively small size. The possibility to analyze complex models using small samples is one of the advantages of PLSSEM when compared to covariance-based SEM. In PLS-SEM, the minimum sample size is calculated according to the number of directed arrows going into the latent variables within the specified model, the statistical power, and a minimum value of explained variance with its corresponding statistical significance (Hair, Hult, Ringle, \& Sarstedt, 2017). In this study, a model consisting of seven parameters of this type was analyzed. With a statistical power of $80 \%$ (commonly used statistical power), and a minimum explained variance of $0.25 \mathrm{p}>0.01$ (considered weak as indicated below), the sample gathered had to be greater than 69 observations. The authors of the study analyzed the data corresponding to 98 observations. The measurement scale was evaluated first. The reliability of the scales was evaluated using Cronbach's alpha coefficients (a) 
and the coefficient of composite reliability (CR), and the rule of thumb for both coefficients was $>0.70$ (Nunnally \& Bernstein, 1994). These two coefficients are used in PLS-SEM to assess this psychometric property (Hair, Ringle, \& Sarstedt, 2011). The collinearity of the items was assessed using the Variance Inflation Factor (VIF) coefficients; values equal to or greater than 0.50 indicate collinearity and, as such, problems in model estimation (Hair et al., 2011). To account for evidence with respect to the convergent validity that would be part of the validity of the tests in relation to other variables, we examined the factorial loads and used the Average Variance Extracted (AVE) coefficient. Factorial loads with values greater than 0.60 and AVE greater than 0.50 reveal convergent validity for the constructs analyzed (Hair et al., 2017). The HeterotraitMonotrait Ratio of Correlations (HTMT) coefficient was considered in order to calculate the discriminant validity of the constructs. Values of less than 0.90 for this coefficient indicate that the constructs are subject to discriminant validity (Hair et al., 2017). The authors subsequently calculated the structural model, assessing construct collinearity using VIF and the same critical values mentioned above (Hair et al., 2011). They then used bootstrapping to calculate the significance of the sequences specified in the model.

Table 1

Measurement model and predictability of the structural model

\begin{tabular}{llllll}
\hline Variable & $a$ & $C F C$ & AVE & $R^{2}$ & $Q^{2}$ \\
\hline Separation Anxiety & 0.88 & 0.9 & 0.59 & 0.31 & 0.16 \\
Motor Impulsivity & 0.77 & 0.83 & 0.55 & & \\
Plan Modification & 0.82 & 0.88 & 0.65 & 0.33 & 0.2 \\
Emotional Expression & 0.89 & 0.92 & 0.74 & 0.6 & 0.51 \\
Attention Seeking & 0.71 & 0.87 & 0.77 & 0.31 & 0.19 \\
Anxiety & 0.9 & 0.91 & 0.47 & 0.13 & 0.04 \\
Depression & 0.86 & 0.88 & 0.52 & 0.07 & 0.02 \\
Fear of Solitude & 0.83 & 0.89 & 0.65 & & \\
\hline
\end{tabular}

All the constructs showed convergent validity, as all the HTMT coefficients fell below the critical value. Some of the items were eliminated given their low factorial loads. The items of the borderline expression factor did not reach the expected value and so were eliminated from the model. The items and factors that were kept are shown in Figure 1
Instead of assessing the general goodness of fit through a series of coefficients, as used in covariancebased SEM models, in PLS-SEM the structural model is evaluated according to its predictive accuracy (Hair et al., 2017), assessed by evaluating the magnitude of the explained variance (R2) of each of the endogenous variables. $R 2$ values of $0.75,0.50$, or 0.25 are considered substantial, moderate, and weak respectively (Hair et al., 2011). To evaluate the size of the effect of the constructs, we used the f2 coefficient. Values of 0.02 , 0.15 , and 0.35 represent small, medium, and substantial effect sizes, respectively (Cohen, 1988). As well as R2, the Stone-Geisser (Q2) value was examined to establish the model's predictive accuracy. Values greater than zero for the endogenous variables are indicative of the model's predictive power. Smart PLS (v 3.2.7) was used for all analyses (Ringle, Wende, \& Bender, 2015).

\section{Results}

The measurement model presented satisfactory results and the scales showed good reliability indices. There were no problems of collinearity in relation to the items (VIF $<0.50$ ), and the constructs passed the convergent validity test (Table 1).
There were no collinearity problems for the constructs. All of the sequences specified in the model shown in Figure 1 were statistically significant (Table 2). The explained variances were weak to moderate in the case of depression (Figure 1). Three of the factors analyzed were small and the others reached moderate and substantial sizes (see Table 2). The values (Q2) indicate the predictive accuracy of the model (Table 1). As a result, the authors decided to keep the model in Figure 1. 


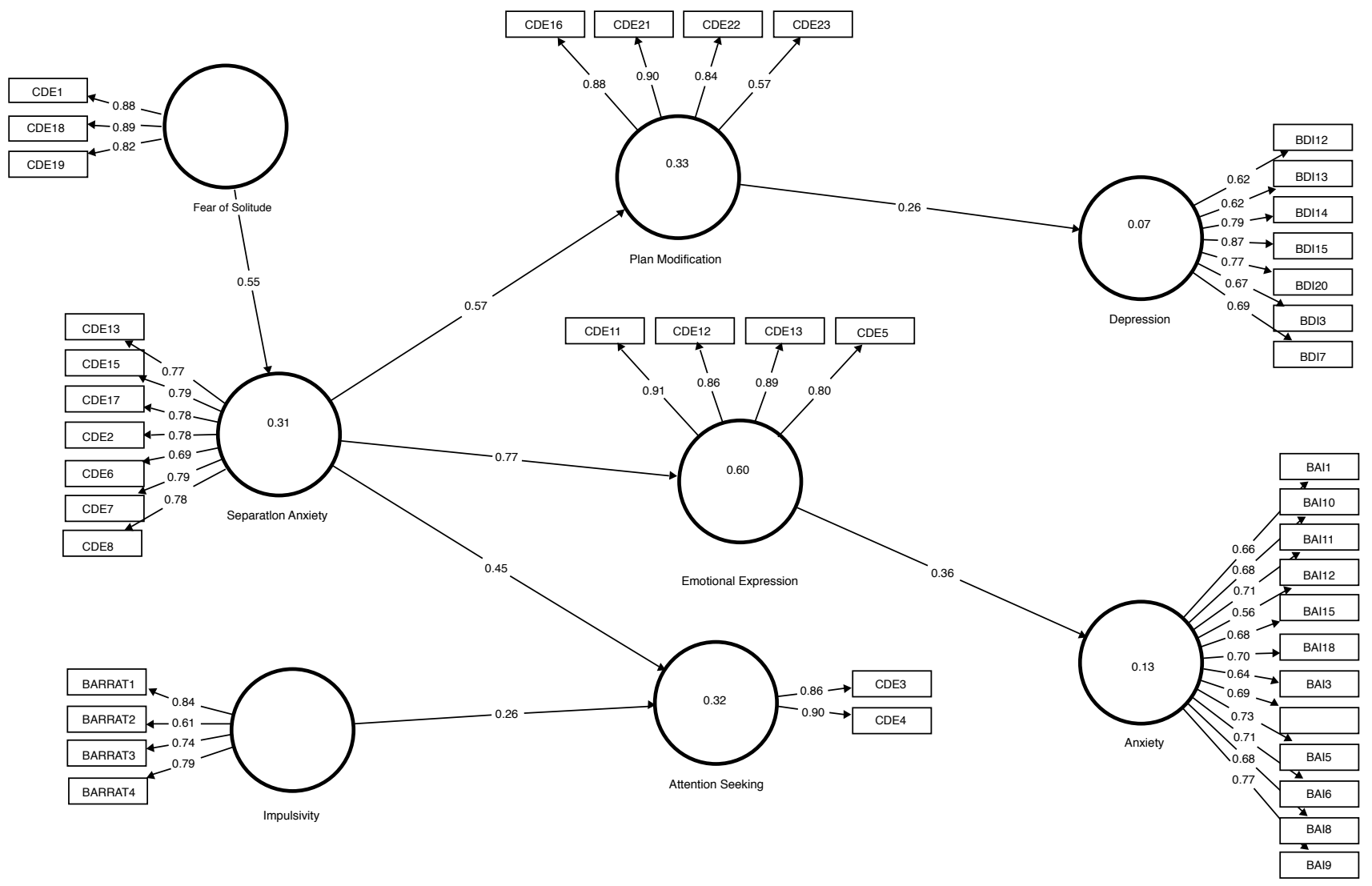

Figure 1. Structural model: ED subescales and its relation with depression, anxiety and impulsivity

Table 2.

PLS-SEM structural-model results

\begin{tabular}{lllll}
\hline Sequences & $\beta$ & $f^{2}$ & Classification & VIF \\
\hline FS to SA & $0.55^{* * *}$ & 0.44 & Substantial & 1.00 \\
SA to PM & $0.57 * * *$ & 0.49 & Substantial & 1.00 \\
SA to SEE & $0.77^{* * *}$ & 1.48 & Substantial & 1.00 \\
SA to AS & $0.45^{* * *}$ & 0.29 & Medium & 1.00 \\
MI to AS & $0.26 * *$ & 0.10 & Small & 1.04 \\
PM to Depression & $0.26 *$ & 0.07 & Small & 1.00 \\
SEE to Anxiety & $0.36 * *$ & 0.15 & Small & 1.00 \\
\hline
\end{tabular}

Nota. FS: Fear of Solitude, SA: Separation Anxiety, PM: Plan Modification, SEE: search for emotional expression, AS: Attention Seeking, MI: Motor Impulsivity. ${ }^{*} p<0.05,{ }^{* *} p<0.01,{ }^{* \star *} p<0.001$.

\section{Discussion}

This study analyzed the relationship between the components of ED with symptoms of anxiety, depression, and impulsivity. The results show that fear of being alone is associated with separation anxiety, which leads to plan modification, the need for emotional expression and attention-seeking behavior. Plan modification is associated with depression; emotional expression with anxiety; and impulsivity as a trait is associated with attention-seeking behavior.

The relationship between fear of being alone and separation anxiety can be explained through development theories, as children develop attentionseeking behaviors and clinging as part of the restoration of attachment when they feel lonely (Grossmann, Grossmann, Kindler, \& Zimmermann, 2008; Waters, Merrick, Treboux, Crowell, \& Albersheim, 2000). 
This was considered by Izquierdo and Gómez-Acosta (2013) in their review of dependency from a contextual perspective. In this respect, studies reveal the existence of a relationship between ED and attachment (AlonsoArbiol, Shaver, \& Yarnoz, 2002; Loinaz \& Echeburúa, 2012). It is worth noting that the studies by AlonsoArbiol et al. (2002) and by Valle and Moral (2018) reported greater association with a preoccupied attachment style and a lesser degree of association with a fearful attachment style. That is, individuals with ED tend to see themselves negatively and the difference between the two types of attachment would be given by the perspective of others, which fluctuates as negative in the fearful, and positive in the preoccupied (Bartholomew \& Horowitz, 1991). Consistent results were reported by Estévez et al. (2018) in a study involving Spanish teenagers in which they found that ED was associated with parental permissiveness and childhood trauma. These results also explain the theory proposed by Karakurt (2012) on jealousy in Turkish university students, who found that a model of self and a model of others affects attachment styles and jealousy; as well as that of Guzmán and Contreras (2012) who concluded that individuals with a negative view of themselves would tend to manifest preoccupation and fear when faced with abandonment by the attachment figure, and vice versa.

This study also found that separation anxiety triggers plan modification, a search for emotional expression, and attention seeking. In separation anxiety and fear of being alone, it is perceived threats (Lemos \& Londoño, 2006; Lemos, Londoño, \& Zapata, 2007) that lead to the deployment of active control strategies (search for emotional expression, plan modification, and attention-seeking) aimed at leading the individual to becoming the center of the partner's life. In this respect, studies have shown that women with ED tend to neglect their own needs and distance themselves from friends and relatives because of the partner (AmadorVelázquez, Torres-Hernández \& Rodríguez García, 2015; Villa Moral Jiménez \& Sirvent Ruiz, 2009). These strategies, in the same way as the search for emotional expression, constitute ways in which people with ED can feel secure vis-á-vis the mistrust they feel (Salamanca \& Forero, 2014; González-Jiménez \& Hernández-Romera, 2014).

It is worth mentioning that according to Ferreyra, Rueckner, Cambiaso, and Paredes (2004), these strategies to control and subordinate the partner as well as the fear of abandonment emerge from unrealistic relationship expectations and the manifestation of irrational demands such as you should and the catastrophic thinking of an inflexible personal style. This coincides with what has been proposed with regards to the cognitive profile of individuals with ED (Lemos, Jaller, González, Díaz, \& De La Ossa, 2012).
Studies on contemporary relationship styles confirm the same results. Estévez et al. (2017) showed that Internet and cell phone addiction are associated with an avoidance of being alone, which in this case involves virtual attention-seeking and is something that has been confirmed in young Colombian couples (Espinar, Zych, \& Rodríguez-Hidalgo, 2015).

Finally, this study found that impulsivity and separation anxiety lead to attention seeking in individuals with ED. The fact that this is the only component to be associated with impulsivity leads us to hypothesize about whether it is this strategy that gives rise to the relationship between ED and suicidal behavior (Siabato \& Salamanca, 2015) or whether it is this component that explains the association between $\mathrm{ED}$ and violence in love relationships (Aiquipa, 2015; Romero-Martínez \& Moya-Albiol, 2013). The latter may be true because it has been found that attentionseeking is greater in men (Lemos \& Londoño, 2006) and that high levels of ED in men predict physical aggression against the partner (Bornstein, 2006). This factor differs from what Estévez et al. (2018) reported for Spanish teenagers, wherein impulsivity was found to be related to all ED components. The difference in the results may be due to the use of different questionnaires to measure ED; however, it is worth pointing out that the study mentioned above found that ED mediates the relationship between impulsivity and attachment, thus acknowledging that impulsivity, rather than being a factor that emerges from ED, leads people with ED to manifest clinging behavior.

Anxiety and depression are strongly associated to ED (Santamaría et al., 2015; Siabato \& Salamanca, 2015). Depression was shown to be directly associated with plan modification, whereby the modification of the individual's own plans to reduce separation anxiety would lead the individual with ED to put off activities that he or she finds gratifying or pleasant. This aspect has been related to the precipitation of depressive disorders (Dimidjian, Martell, Addis, \& Herman-Dunn, 2008), and may also be related to the result found by Estévez et al. (2017), in that plan modification could play a role as a strategy used by the individual with ED to avoid being alone, particularly when the partner fills an emotional void. Finally, this would explain the results found by Ruiz (2013), who saw that in interventions, individuals with ED who went back to previous activities and again became close with their friends and relatives were able to improve their depressive symptoms.

This study found an association between anxiety and the search for emotional expression from the partner. Demanding affection is an active strategy used by the individual with ED to reduce anxiety (Lemos \& Londoño, 2006), whereby if the individual with ED does not receive the appropriate response, the anxiety will increase, and if he or she does receive the appropriate 
response, this will reinforce the tendency to continue to seek emotional expression (Clark \& Beck, 2010). This has also been described by González-Jiménez and Hernández-Romera (2014) for Spanish teenagers. It is worth mentioning that the results found here refer to the association between anxiety and one of the interpersonal strategies used by individuals with ED, in contrast to Spanish studies which have found that it is an avoidance of being alone that is associated with anxiety and depression (Estévez et al., 2017; Urbiola et al., 2017).

This article contributes knowledge with regards to the treatment of ED by creating a model of its functioning that allows health professionals to consider it as based in the individual and stretching out to cover the global situation and vice versa. For example, when patients with ED present depressive symptomatology, this model can lead us to think that plan modificationwhich enables coping with separation-anxiety-may have failed, but that it functions to perpetuate depressive symptoms. The model also allows us to approach anxiety symptoms through the exploration of the presence of an active search for emotional expression strategy, where an active attention-seeking strategy allows us to explore the presence of a personality trait of impulsivity. Finally, the model could be used as theoretical support for the design of prevention or early intervention plans for the population at risk of ED in the stages in which the active strategies begin to emerge.

This article has a number of limitations. Given that it is a cross-sectional study, the relations made explicit here were modeled using structural equations. As a result, they cannot determine whether what we are dealing with are causal relationships or risk ones. Rather, these are based on the theoretical models and scientific evidence currently available. It was also necessary to eliminate the borderline expression component from the analysis given its low prevalence in the participants. Finally, it is important to point out that the sample analyzed belongs to private universities in Medellín, which may limit the generalization of results to other populations. It is therefore important to develop future studies involving populations with different age ranges, and clinical populations that shed light on the importance of these components in ED and their relationship with emotional symptomatology.

In sum, this study describes the relationships between the components of ED and symptoms of anxiety, depression, and impulsivity. It also explains the association between the symptomatology and behaviors associated in ED, pointing out the course of its development such as, for example, the fact that a fear of being alone may trigger depression or anxiety according to the strategy used.

\section{References}

Ahmadzad-Asl, M., Davoudi, F., Zarei, N., MohammadSadeghi, H., \& Rasoulian, M. (2016). Domestic violence against women as a risk factor for depressive and anxiety disorders: findings from domestic violence household survey in Tehran, Iran. Archives of Women's Mental Health, 19(5), 861-869. doi:10.1007/s00737-016-0626-4

Aiquipa, J. (2015). Dependencia emocional en mujeres víctimas de violencia de pareja. Revista de Psicología, 33(2), 412-437.

Alonso-Arbiol, I., Shaver, P. R., \& Yarnoz, S. (2002). Insecure Attachment, Gender Roles, and Interpersonal Dependency in the Basque Country. Personal Relationships, 9(4), 479-490. doi:10.1111/1475-6811.00030

Álvarez-Dardet, S., Pérez-Padilla, J. P., \& Lorence-Lara, B. (2013). La violencia de pareja contra la mujer en España: Cuantificación y caracterización del problema, las víctimas, los agresores y el contexto social y profesional. Psychosocial Intervention, 22(1), 41-53. doi:10.5093/in2013a6

Amador-Velázquez, R., Torres-Hernández, A., \& Rodríguez García, C. (2015). El descuido de sí misma en el proceso de Enamoramiento-Amor. Revista Electrónica Medicina, Salud y Sociedad, 5(2), 121-139. Recovered from http://hdl. handle.net/20.500.11799/32407

Ballarotto, G., Volpi, B., Marzilli, E., \& Tambelli, R. (2018). Adolescent Internet Abuse: A Study on the Role of Attachment to Parents and Peers in a Large Community Sample. BioMed Research International, 2018, 1-10. doi:10.1155/2018/5769250

Bartholomew, K., \& Horowitz, L. M. (1991). Attachment styles among young adults: A test of a four-category model. Journal of Personality and Social Psychology, 61(2), 226-244. doi:10.1037/0022-3514.61.2.226

Beck, A. T., \& Steer, R. A. (2011). Inventario de Ansiedad de Beck. (J. Sanz, Trans.). Madrid: Pearson.

Beck, A. T., Steer, R. A., \& Brown, G. K. (2011). BDIII. Inventario de Depresión de Beck II. (J. Sanz, Trans.). Madrid: Pearson.

Beck, A. T., Ward, C. H., Mendelson, M., Mock, J., \& Erbaugh, J. K. (1961). An inventory for measuring depression. Archives of General Psychiatry, 4(6), 561-571. doi:10.1001/ archpsyc. 1961.01710120031004

Bornstein, R. F. (1998). Dependency in the personality disorders: Intensity, insight, expression, and defense. Journal of Clinical Psychology, 54(2), 175-189. doi:10.1002/ (SICI) 1097-4679(199802)54:2\%3C175::AIDJCLP7\%3E3.0.CO;2-R 
Bornstein, R. F. (2006). The complex relationship between dependency and domestic violence: Converging psychological factors and social forces. American Psychologist, 61(6), 595-606. doi:10.1037/0003-066X.61.6.595

Bution, D. C., \& Wechsler, A. M. (2016). Dependência emocional: uma revisão sistemática da literatura. Estudos Interdisciplinares Em Psicologia, 7(1), 77. doi:10.5433/2236-6407.2016v7n1p77

Caplan, S. E. (2007). Relations Among Loneliness, Social Anxiety, and Problematic Internet Use. CyberPsychology \& Behavior, 10(2), 234-242. doi:10.1089/cpb.2006.9963

Castelló, J. (2002, December). Tratamiento de la dependencia emocional en la mujer. Ponencia presentada en el II Symposium Nacional de Adicción en la Mujer, Fundación Instituto Spiral. Madrid, España.

Castelló, J. (2005). Dependencia emocional. Características y tratamiento. Madrid: Alianza Editorial.

Clark, D. A., \& Beck, A. T. (2010). Cognitive therapy of anxiety disorders: science and practice. New York: Guilford Press.

Cohen, J. (1988). Statistical power analysis for the behavioral sciences. Mahwah, NJ: Lawrence Erlbaum.

Davila, J., Steinberg, S. J., Kachadourian, L., Cobb, R., \& Fincham, F. (2004). Romantic involvement and depressive symptoms in early and late adolescence: The role of a preoccupied relational style. Personal Relationships, 11(2), 161-178. doi:10.1111/j.1475-6811.2004.00076.x

de la Villa, M., García, A., Cuetos. G., \& Sirvent. C. (2017). Violencia en el noviazgo, dependencia emocional y autoestima en adolescentes y jóvenes españoles. Revista Iberoamericana de Psicología y Salud, 8(2), 96-107. doi:10.23923/j. rips.2017.08.009

Del Castillo, A., Hernández, M., Romero, A., \& Iglesias, S. (2015). Violencia en el noviazgo y su relación con la dependencia emocional pasiva en estudiantes universitarios. Psicumex, 5(1), 4-18.

Dimidjian, S., Martell, C. R., Addis, M. E., \& HermanDunn, R. (2008). Behavioral activation for depression. In Clinical handbook of psychological disorders: A step-by-step treatment manual (pp. 328-364). New York: Guilford Press. doi:10.1017/s0813483900008020

Espinar, E., Zych, I., \& Rodríguez-Hidalgo, A. J. (2015). Ciberconducta y dependencia emocional en parejas jóvenes. Psychology, Society, \& Education 7(1), 41-55 http://dx.doi.org/10.25115/psye. v7i1.539
Estévez, A., Chávez-Vera, M. D., Momeñe, J., Olave, L., Vázquez, D., \& Iruarrizaga, I. (2018). El papel de la dependencia emocional en la relación entre el apego y la conducta impulsiva. Anales de Psicología / Annals of Psychology, 34(3), 438445. doi:10.6018/analesps.34.3.313681

Estévez, A., Urbiola, I., Iruarrizaga, I., Onaindia, J., \& Jauregui, P. (2017). Dependencia emocional y consecuencias psicológicas del abuso de internet y móvil en jóvenes. Anales de Psicología, 33(2), 260. doi:10.6018/analesps.33.2.255111

Ferreyra, D. C., Rueckner, G. E., Cambiaso, A. G., \& Paredes, M. T. (2004). Intervención cognitivoconductual en un grupo de pacientes mujeres con dependencia afectiva. Revista de Psiquiatría y Salud Mental Hermilio Valdizan, V(2), 81-90.

González-Jiménez, A. J., \& Hernández-Romera, M. del M. (2014). Emotional Dependency Based on the Gender of Young Adolescents in Almeria, Spain. Procedia - Social and Behavioral Sciences, 132, 527-532. doi:10.1016/j.sbspro.2014.04.348

Grossmann, K., Grossmann, K. E., Kindler, H., \& Zimmermann, P. (2008). A wider view of attachment and exploration: The influence of mothers and fathers on the development of psychological security from infancy to young adulthood. In J. Cassidy \& P. R. Shaver (Eds.), Handbook of attachment: Theory, research, and clinical applications (pp. 857-879). New York: Guilford Press.

Guzmán, M., \& Contreras, P. (2012). Estilos de Apego en Relaciones de Pareja y su Asociación con la Satisfacción Marital. Attachment Styles in Couples and Their Association With Marital Satisfaction. Psykhe, 21(1), 69-82. doi:10.4067/ s0718-22282012000100005

Hair, J. F., Hult, G. T. M., Ringle, C., \& Sarstedt, M. (2017). A Primer on Partial Least Squares Structural Equation Modeling (PLS-SEM) (2nd ed.). Los Angeles, Calif.: Sage.

Hair, J. F., Ringle, C. M., \& Sarstedt, M. (2011). PLSSEM: Indeed a silver bullet. Journal of Marketing Theory and Practice, 19(2), 139-151. https:// doi.org/10.2753/mtp1069-6679190202

Hernández, R., Fernández, C., \& Baptista, P. (2006). Metodología de la investigación (4a ed.). México; Bogotá: McGraw Hill.

Hirschfeld, R. M. A., Klerman, G. L., Gouch, H. G., Barrett, J., Korchin, S. J., \& Chodoff, P. (1977). A Measure of Interpersonal Dependency. Journal of Personality Assessment, 41(6), 610-618. doi:10.1207/s15327752jpa4106_6

Ho, R. C., Zhang, M. W. B., Tsang, T. Y., Toh, A. H., Pan, F., Lu, Y., ... Mak, K.-K. (2014). The association between internet addiction and psychiatric comorbidity: a meta-analysis. BMC Psychiatry, 14(1), 284-306. doi:10.1186/1471-244x-14-183 
Izquierdo, S.A., \& Gómez-Acosta,A. (2013).Dependencia afectiva: abordaje desde una perspectiva contextual. Psychologia. Avances de La Disciplina, 7(1), 81-91. doi:10.21500/19002386.1196

Jaller, C., \& Lemos, M. (2009). Esquemas desadaptativos tempranos en estudiantes universitarios con dependencia emocional. Acta Colombiana de Psicología, 12(2), 77-83.

Karakurt, G. (2012). The Interplay Between Self Esteem, Feeling of Inadequacy, Dependency, and Romantic Jealousy as a Function of Attachment Processes Among Turkish College Students. Contemporary Family Therapy, 34(3), 334-345. doi:10.1007/s10591-012-9185-7

Lemos, M., Jaller, C., González, A. M., Díaz, Z. T., \& De La Ossa, D. (2012). Perfil cognitivo de la dependencia emocional en estudiantes universitarios en Medellín, Colombia. Universitas Psychologica, 11(2), 1657-9267. Retrieved from http://ref.scielo.org/y5n5sb

Lemos, M., \& Londoño, N. (2006). Construcción y validación del cuestionario de dependencia emocional en población Colombiana. Acta Colombiana de Psicología, 9(2), 127-140.

Lemos, M., Londoño, N., \& Zapata, J. (2007). Distorsiones cognitivas en personas con dependencia emocional. Informes Psicológicos, 9(9), 55-69.

Lemos, M., Vásquez-Villegas, C., Román-Calderón, J.P. (2019). Invarianza del Cuestionario de Dependencia Emocional entre sexos y situación sentimental en universitarios. Revista de Psicología, 37(1), 218-250. doi:10.18800/ psico.201901.008

Lewis, J. B., Sullivan, T. P., Angley, M., Callands, T., Divney, A. A., Magriples, U., ... Kershaw, T. S. (2017). Psychological and relational correlates of intimate partner violence profiles among pregnant adolescent couples. Aggressive Behavior, 43(1), 26-36. doi:10.1002/ab.21659

Loinaz, I., \& Echeburúa, E. (2012). Apego adulto en agresores de pareja. Adult attachment in partnerviolent men. Acción Psicológica, 9(1), 33-46. https://doi.org/10.5944/ap.9.1.435

Morse, J. Q., Robins, C. J., \& Gittes-Fox, M. (2002). Sociotropy, autonomy, and personality disorder criteria in psychiatric patients. Journal of Personality Disorders, 16(6), 549-560. doi:10.1521/pedi.16.6.549.22140

Najafi, M., Mamazandi, Z. K., \& Balutbangan, A. A. (2017). The relationship of anxiety, stress, and depression with suicidal thoughts among female adolescents: The meditating role of victim of bullying. Journal of Fundamentals of Mental Health, 19(5), 401-407. https://doi. org/10.22038/jfmh.2017.9312
Nunnally, J. C., \& Bernstein, I. H. (1994). Psychometric theory (3rd ed.). New York: McGraw-Hill.

Oquendo, M. A., Baca-García, E., Graver, R., Morales, M., Montalvan, V., \& Mann, J. J. (2001). Spanish adaptation of the Barratt impulsiveness scale (BIS-11). The European Journal of Psychiatry, 15(3), 147-155.

Orozco-Cabal, L., Rodríguez, M., Herin, D. V., Gempeler, J., \& Uribe, M. (2010). Validity and reliability of the abbreviated Barratt Impulsiveness Scale in Spanish (BIS-15S). Revista Colombiana de Psiquiatria, 39(1), 93-109. https://doi. org/10.1016/s0034-7450(14)60239-0

Palmier-Claus, J. E., Taylor, P. J., Varese, F., \& Pratt, D. (2012). Does unstable mood increase risk of suicide? Theory, research and practice. Journal of Affective Disorders, 143(1-3), 5-15. doi:10.1016/j.jad.2012.05.030

Patton, J. H., Stanford, M. S., \& Barratt, E. S. (1995). Factor structure of the Barratt impulsiveness scale. Journal of Clinical Psychology, 51(6), 768-774.

Poorakbaran, E. (2015). Assessment of using of emerging communication tools (cell phone, internet and satellite) among young adults and its association with anxiety, depression and stress. Journal of Fundamentals of Mental Health, 17(5), 254-259.

Preciado-Gavidia, P. M., Torres-Cendales, N. E., \& Rey-Anacona, C. A. (2012). Mujeres que finalizaron una relación maltratante: características de personalidad, psicopatológicas y sociodemográficas. Universitas Psychologica, 11(1), 43-54. doi:10.11144/Javeriana.upsy11$1 . \mathrm{mfrm}$

Rathus, J. H., \& O'Leary, K. D. (1997). SpouseSpecific Dependency Scale: Scale Development. Journal of Family Violence, 12(2), 159-168. doi:10.1023/A:1022884627567

Reed, P., Romano, M., Re, F., Roaro, A., Osborne, L. A., Viganò, C., \& Truzoli, R. (2017). Differential physiological changes following internet exposure in higher and lower problematic internet users. PLOS ONE, 12(5), 1-11. doi:10.1371/journal. pone. 0178480

Ringle, C. M., Wende, S., \& Bender, J.-M. (2015). SmartPLS 3. Boenningstedt: SmartPLS GmbH. Retrieved from http://www.smartpls.com

Romero-Martínez, Á., \& Moya-Albiol, L. (2013). Neuropsychology of perpetrators of domestic violence: the role of traumatic brain injury and alcohol abuse and/or dependence. Revista de Neurología, 57(11), 515-522.

Ruiz, M. S. (2013). Dependencia emocional: características e intervención, análisis de dos casos clínicos. Universidad Autónoma de Nuevo León. Retrieved from http://eprints.uanl.mx/3806/ 
Salamanca, Y., \& Forero, I. X. (2014). Características psicológicas del estudiante de psicología de una universidad pública de Colombia. Revista de Psicología de Arequipa, 4(2), 129-144.

Santamaría, J. J., Merino, L., Montero, E., Cano, M., Fernández, T., Cubero, P., ... González Bueso, V. (2015). Perfil psicopatológico de pacientes con Dependencia Emocional. Cuadernos de Medicina Psicosomática y Psiquiatria de Enlace, (116), 3646. Retrieved from https://dialnet.unirioja.es/ servlet/articulo? codigo $=5288486$

Sanz, J., García-Vera, M. P., Espinosa, R., Fortún, M., \& Vázquez, C. (2005). Adaptación española del Inventario para la Depresión de Beck-II (BDI-II): 3. Propiedades psicométricas en pacientes con trastornos psicológicos. Clínica y Salud, 16(2), 121-142.

Sanz, J., \& Navarro, M. E. (2003). Propiedades psicométricas de una versión española del Inventario de Ansiedad de Beck (BAI) en estudiantes universitarios. Ansiedad y Estrés, 9(1), 59-84.

Sanz, J., Navarro, M. E., \& Vázquez, C. (2003). Adaptación española del inventario para la depresión de beck--II(BDI-II): 1. Propiedades psicométricas en estudiantes universitarios [Spanish adaptation of the Beck Depression Inventory-II (BDI-II): 1. Psychometric properties with university students]. Análisis y Modificación de Conducta, 29(124), 239-288.

Sanz, J., Perdigón, A. L., \& Vazquez, C. (2003). Adaptación española del Inventario para la depresión de Beck II (BDI II): 2. Propiedades psicométricas en población general. Clínica y Salud, 14(3), 249-280.

Schaeffer, B. (1998). ¿Es amor o es adicción? Barcelona: Apóstrofe.

Shaikh, A., Pearce, B., \& Yount, K. (2017). Effect of Enabling Resources and Risk Factors on the Relationship between Intimate Partner Violence and Anxiety in Ever-Married Women in Minya, Egypt. Journal of Family Violence, 32(1), 13-23. doi:10.1007/s10896-016-9848-5

Siabato, E. F., \& Salamanca, Y. (2015). Factores asociados a ideación suicida en universitarios. Psychologia: Avances de La Disciplina, 9(1), 7181. Retrieved from http://www.scielo.org.co/ pdf/psych/v9n1/v9n1a06.pdf

Sirvent, C. (2000). Las dependencias relacionales: dependencia emocional, codependencia y bidependencia. In I Symposium nacional sobre adicción en la mujer (pp. 164-215). Madrid: Instituto de la Mujer y Fundación Instituto Spiral. Retrieved from http://fispiral.com.es/ wp-content/uploads/2002/03/I-symposiumsobre-adiccion-en-la-mujer.pdf
Spinella, M. (2007). Normative data and a short form of the Barratt Impulsiveness Scale. International Journal of Neuroscience, 117(3), 359-368. doi:10.1080/00207450600588881

Urbiola, I., Estévez, A., \& Iraurgi, I. (2014). Dependencia Emocional en el Noviazgo de Jóvenes y Adolescentes (DEN): Desarrollo y validación de un instrumento. Ansiedad y Estres, 20(2-3), 101-114.

Urbiola, I., Estévez, A., Iruarrizaga, I., \& Jauregui, P. (2017). Dependencia emocional en jóvenes: relación con la sintomatología ansiosa y depresiva, autoestima y diferencias de género. Ansiedad y Estrés, 23(1), 6-11. doi:10.1016/j. anyes.2016.11.003

Valle, L., \& Moral, M. de la V. (2018). Dependencia emocional y estilo de apego adulto en las relaciones de noviazgo en jóvenes españoles. Revista Iberoamericana de Psicología y Salud, 9(1), 27-41. doi:10.23923/j.rips.2018.01.013

Villa Moral Jiménez, M. D. L., \& Sirvent Ruiz, C. (2009). Dependencia Afectiva y Género: Perfil Sintomático Diferencial en Dependientes Afectivos Españoles. Interamerican Journal of Psychology, 43(2), 230-240.

Waters, E., Merrick, S., Treboux, D., Crowell, J., \& Albersheim, L. (2000). Attachment security in infancy and early adulthood: a twenty-year longitudinal study. Child Development, 71(3), 684-689. doi:10.1111/1467-8624.00176

Wiener, C. D., Moreira, F. P., Zago, A., Souza, L. M., Branco, J. C., de Oliveira, J. F., ... Oses, J. P. (2018). Mood disorder, anxiety and suicide risk among subjects with alcohol abuse and/ or dependence: a population-based study. Revista Brasileira de Psiquiatria, 40(1), 1-5. doi:10.1590/1516-4446-2016-2170 